\title{
HAKIKAT WUJUD: SEBUAH KLASIFIKASI
}

\author{
Oleh: \\ Husnul Khatimah \\ STAIN Nurul Huda Kapongan \\ Hkhatimah257@gmail.com
}

\begin{abstract}
:
When traced by human thoughts, everyone agree that everything that exists do not exist by itself, except for a small part which according to reason, may exist without going through intermediaries. Therefore, any original object that can be transformed into various forms, become these origins have special traits and characteristics, and can be changed to another form. For example water. Water rises into the air into clouds then drops to rain, and winter to snow that is at a time becomes gas. Alshahrastani said that in the opinion of "Anaxagoras" the origins of the body are the subtle dhat. Are the human senses and the intellect can not reach, from the dhat arises the upper and lower realms composed of the very simple dhat that make up the various forms. Unlike the exposure of Al-Ghazali that form is classified into four gradual categories: the true or dhati, the form in the mental subject, the form in the oral, and the form in writing. While the actual being is already there in concrete, real, which in the end is called necessitas, mandatory al-wujud and also potential form is something that still exist in the concept of ideas and ready to be concrete that known space and time.
\end{abstract}

Key Words: Hakikat, Wujud, Tasawuf

\section{A. Pendahuluan}

Kesempurnaan manusia adalah karena ketidak sempurnaannya itu, sehingga ia selalu bertanya, dan gelisah akan hal-hal yang melingkupi kehidupanya, realitas kosmologi dan sebagainya. Pertanyaan yang paling dasar adalah ketika manusia gusar tentang eksistensi alam, "siapakah kita...? yang melahirkan tentang filsafat manusia, siapa Pencipta kita ...? yang melahirkan berbagai pandangan tentang konsep ketuhanan, asal usul alam semesta, ia real atau tidak dan lain sebagainya". Yang muaranya adalah berbicara tentang eksistensi, wujud (being).

Wujud adalah persoalan yang sangat penting dan fundamental dalam filsafat Islam. Perdebatan antara kaum peripateik, iluminisme, dan transendentalisme mengenai topik ini merupakan perjalanan panjang 
yang terus-menerus mewarnai ranah pemikiran filsafat Islam yang teramat luas dan dalam.

Dalam tradisi filsafat Islam, wujud mempunyai pengertian yang sangat beragam, hal ini tentu di ilhami oleh latar belakang dan model pemikiran yang dimiliki oleh para filusuf Islam. Selain menjadi kajian utama dari segala sesuatu, wujud juga menjelaskan berbagai realitas. Wujud merupakan salah satu tema metafisika yang banyak melahirkan kontroversi filosofis, karena hakikatnya sangat sulit untuk bisa dipahami ${ }^{1}$.

\section{B. Pembahasan}

\section{Definisi Hakikat}

Secara etimologis, kata "hakikat" berasal dari bahasa Arab "haqiqat" berarti "yang benar", "yang sebenarnya", "kenyataan" yang menjadi isi "al-haqq" (kebenaran dalam arti "putusan yang sesuai dengan kenyataan"), dan "sesuatu yang tetap secara pasti dan meyakinkan". Karena itu, ahli semantik memakainya untuk menunjuk kata yang tetap pada maknanya yang asli, lawan majaz (metafor) ${ }^{2}$.

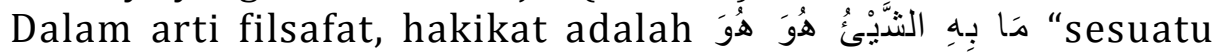
yang dengannya sesuatu adalah dirinya." Sebagai contoh adalah "hewan yang bisa berfikir" bagi manusia, yang menunjuk kenyataan terdalam yang inhern di dalam sesuatu. Ia dari sudut kenyataan adanya dalam realitas objektif-aktual disebut "haqiqat", dari sudut perwujudan individualnya yang membedakan sesuatu dari yang lain disebut "huwiyyah", dan apabila tidak memerhatikan kedua aspek tersebut disebut "mahiyyah". "Haqiqat" dalam ketiga arti terakhir di atas identik dengan "esensi".

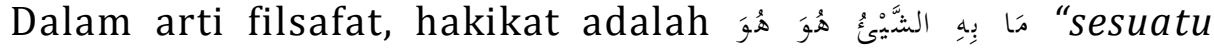

yang dengannya sesuatu adalah dirinya." Sebagai contoh adalah "hewan yang bisa berfikir" bagi manusia, yang menunjuk kenyataan terdalam yang inhern di dalam sesuatu. Ia dari sudut kenyataan adanya dalam realitas objektif-aktual disebut "haqiqat", dari sudut perwujudan individualnya yang membedakan sesuatu dari yang lain disebut "huwiyyah", dan apabila tidak memerhatikan kedua aspek tersebut disebut "mahiyyah".3 "Haqiqat" dalam ketiga arti

1 Zaedi Basitur Rozak, "Eksistensialisme Persfektif Filsafat Mulla Sadra", dalam http://www.blogspot.com. eksistensialisme-persfektif-filsafat.html, (Juli 2017), 1.

${ }^{2}$ Saeful Anwar, Filsafat Ilmu al-Ghazali: Dimensi Ontologi dan Aksiologi, (Bandung: Pustaka Setia, I/2007), hlm. 85.

3 Ibid., dan lihat: Al-Jurjani, Kitab al-Ta'rifat, (Singapur-Jeddah: al-Haramain, t.th.),

$160 \mid$ JURNAL LISAN AL-HAL 
terakhir di atas identik dengan "esensi".

\section{Definisi Wujud ("ada")}

Dalam bahasa Arab, wujud sering dipakai untuk arti being dan existence, sebab tidak ada padanannya, berbeda dengan kana yang bentuk masdar (kata dasar)-nya bisa berarti lain. ${ }^{4}$ Kata wujud adalah bentuk masdar dari wajada atau wujida, yang berasal dari akar $w j d$ (وجد). Akan tetapi tidak terdapat dalam Al-Qur'an bentuk masdar dari akar yang sama, yang ada yaitu masdar wujd dalam ayat:

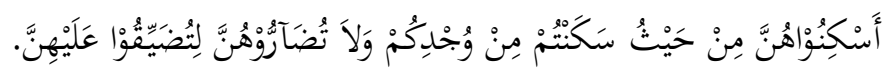

"Tempatkanlah mereka (para istri) dimana kamu bertempat tinggal menurut kemampuanmu, dan janganlah kamu menyusahkan mereka untuk menyempitkan (hati) mereka." 5

Adapun bentuk fi'il dari akar yang sama banyak terdapat dalam AlQur'an, misalnya QS. 3:37, 18:86, 27:23, 93:7, 4:43,18:69, dan 7:157.6 Menurut Al-Ghazali, wujud merupakan konsep dasar yang paling umum meliputi semua maujud (yang ada). Mengetahui makna wujud termasuk pengetahuan a priori (awwaliyyat), seperti semua awwaliyyat lain yang berupa makna simpel dan esensinya sudah diketahui akal secara a priori, tak dapat dan tak perlu didefinisikan. Mencari esensi sesuatu yang a priori dengan definisi sama dengan mencari argumen atas fakta bahwa satu lebih sedikit dari pada dua. Dengan demikian, meragukan wujud sama mustahilnya dengan meragukan eksistensi diri sendiri. Meskipun AlGhazali pernah menolak Mu'tazilah ketika mengatakan bahwa ma'dum (yang tiada) -menurut kami- itu bukan shai' (sesuatu), ${ }^{7}$ ia juga menolak pengidentifikasian maujud dengan shai'. ${ }^{8}$

Dalam analisa terminologi dapat diketemukan bahwa wujud berarti

hlm. 89-90.

${ }^{4}$ Saeful, Ibid. hlm. 123.

5 Al-Qur'an, hlm. 65:66.

6 Kautsar Azhari Noer, Ibn al-'Arabi: Wah\}dat al-Wujud dalam Perdebatan, (Jakarta: Paramadina, I/1995), hlm. 42.

7 Kata-kata "menurut kami" dalam kutipan diatas merupakan indikasi bagi pendirian Al-Ghazali yang sesungguhnya, yaitu bahwa wujud dalam arti eksistensi (aniyyah) merupakan makna tambahan yang tidak termasuk esensi (mahiyyah) sesuatu, dan $m a^{\prime} d u m$ bukan "sesuatu" dalam realitas aktual, tapi "sesuatu" dalam konsep mental. Lihat: Saeful, Filsafat Ilmu al-Ghazali, hlm. 124.

8 Ibid., hlm. 123-124. 
keberadaan yang mempunyai tingkat abstraksi yang tinggi. Dengan demikian dapat dibedakan menurut dimensi masing-masing, bahwa wujud sarat dengaan pergumulan tasawuf, sementara wujud merupakan titik tolak dari filsafat yang sering dibahas dalam diskursus kalam dan filsafat Islam sebagai madhhab wujudiyah (existensialism). ${ }^{9}$

\section{Klasifikasi Wujud}

DR. H. Saeful Anwar, M.A. telah memberikan solusi yang tepat, bahwa kita harus membangun filsafat ilmu diatas lima fondasi sebagai aksioma, postulat, paradigma atau asumsi dasar, yaitu sebagai berikut:

a. Ada sesuatu di luar mental subjek yang mempunyai substansi dan esensi sendiri.

b. Untuk mengetahui atau menangkap substansi dan esensi segala sesuatu selain Allah itu ada jalannya.

c. Manusia sebagai subjek ilmu memiliki potensi dan kapabilitas untuk menelusuri jalan itu.

d. Tangkapan dan pernyataan subjek terhadap objek, atau "gambar" (representasi) objek pada mental subjek dan pernyataannya, yang cocok dan sesuai dengan realitas objek sendiri berdasarkan jalan tertentu, itulah hakikat ilmu.

e. Ilmu adalah untuk kemajuan dan kebahagiaan abadi bagi umat manusia.

Di atas kelima postulat itulah, filsafat ilmu Al-Ghazali sebagai sebuah sistem yang komprehensif dibangun. Empat yang pertama disarikannya dalam statemen berikut:

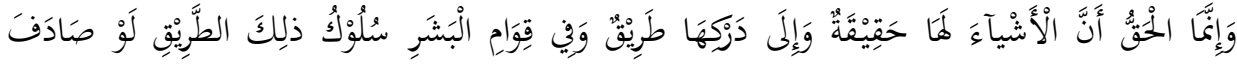

$$
\begin{aligned}
& \text { مُرْنِدًا بَصِيْرًا. } 10
\end{aligned}
$$

"Sesungguhnya yang benar adalah bahwa segala sesuatu itu mempunyai hakikat (esensi). Untuk menangkap hakikat segala sesuatu itu ada

9 The Liang Gie, Pengantar Filsafat Ilmu, (Yogyakarta: Liberty, 2004), hlm. 3.

10 Dalam statemen di atas, kata "haqiqat" diterjemahkan sebagaimana aslinya (hakikat), dengan pemaknaan "esensi", untuk menghindari reduksi dan menunjukkan bahwa yang dimaksud oleh Al-Ghazali adalah esensi dalam arti inti atau kenyataan terdalam dari sesuatu yang inhern di dalam sesuatu itu. Al-Ghazali sering memakai kata haqiqat, mahiyyah dan huwiyyah yang semakna dengan "esensi", yakni "satiyyat al-shai" (jati diri sesuatu), baik dalam arti seperti di atas, yang di lawankan dengan aksiden, eksistensi dan form, maupun dalam arti "universal" seperti dalam definisi "manusia adalah hewan yang bisa berfikir." Lihat: Saeful, Filsafat Ilmu al-Ghazali, hlm. 85-86.

162 JURNAL LISAN AL-HAL 
jalannya. Dan adalah dalam kesanggupan manusia menelusuri jalan itu, jika ia mendapatkan pembimbing yang melihat."11

Berdasarkan kelima asumsi dasar yang menjadi fondasi filsafat ilmunya tersebut, Al-Ghazali mengklasifikasikan wujud kedalam empat kategori gradual berikut semua makna dan implikasi yang dipegangnya secara konsisten. Keempat kategori itu adalah:

a. Wujud hakiki atau dhati (objektif atau aktual) " وجود في الأعيان, وجود في الخارج, حقيقة "الشيئ في نفسه ," yaitu adanya sesuatu dalam realitasnya sendiri.

b. Wujud dalam mental sabjek yang mengetahui (subjektif atau potensial) "وجود في الأذهان, وجود في الداخل" , yaitu menjelmanya gambar atau salinan objek dalam mental sabjek sebagaimana realitas objek sendiri, yang disebut ilmu.

c. Wujud dalam lafal lisan "وجود في اللفظ"

d. Wujud dalam tulisan "وجودو في الكظتابة".

Dua wujud pertama bersifat universal, sedangkan dua wujud berikutnya bersifat simbolik, berbeda-beda menurut perbedaan waktu, tempat dan situasi. Derajat keempat wujud itu hirarkis, yakni yang lebih rendah (luar) menunjukkan yang lebih tinggi (dalam). ${ }^{12}$ Di lain tempat terdapat wujud kelima, wujud shabahi, yaitu bahwa sesuatu sebenarnya tidak ada tetapi ada yang lain yang serupa seperti yang diisyaratkan dalam mimpi. 13

Menurut Ibn 'Arabi, eksistensi adalah wujud dari essensi. Sesuatu bisa dianggap wujud jika termanifestasikan dalam apa yang disebut tahapan wujud (maratib al-wujud), yang terdiri atas empat hal, yaitu: 1) Eksis dalam wujud sesuatu (wujud al-shai' fi 'ainih); 2) Eksis dalam pikiran atau konsepsi (wujud al-shai' fi al-'ilm); 3) Eksis dalam ucapan (wujud alshai' fi al-alfaz\}); dan 4) Eksis dalam tulisan (wujud al-shai' fi al-ruqum). Segala sesuatu bisa dianggap wujud jika ada di antara salah satu empat tahapan tersebut. Sesuatu yang tidak ada di antaranya tidak bisa dianggap sebagai wujud, dan karena itu tidak bisa dibicarakan. ${ }^{14}$

\section{Wujud Aktual dan Potensial}

Dalam kaitannya dengan pengetahuan dan apa yang ditangkap oleh nalar manusia, Al-Ghazali membagi wujud menjadi dua; aktual dan

11 Ibid. hlm. 84-85.

12 Al-Ghazali, Ihya' 'Ulum al-Din. (Beirut: Da>r al-Fikr, t.th.), I/79.

13 Ibid., IV/387.

14 A. Khudori Soleh, Wacana Baru Filsafat Islam, (Yogyakarta: Pustaka Pelajar, I/2004), hlm. 145. 
potensial. Wujud aktual adalah semua realitas yang mempunyai eksistensi di luar mental atau persepsi manusia. Ia mempunyai hakikat pada dirinya sendiri. Realitas ini mencakup semua partikular, baik yang sensual (mahsusat), yakni semua materi dengan semua sifat fisisnya seperti warna, bentuk dan ukuran, maupun partikular non sensual (ghair mahsusat), yakni semua sesuatu yang ada dalam diri kita sendiri yang diketahui secara a priori, seperti potensi panca indra, kemampuan, kehendak, akal dan seterusnya.

Sebaliknya, wujud potensial adalah semua realitas yang eksistensi hanya- ada dalam mental atau pikiran manusia. Wujud ini terbagi dalam tiga bagian; wujud hissi, wujud khayali, dan wujud 'aqli.

a. Wujud hissi adalah sesuatu dalam potensi indra sebagai 'sense datum', yaitu hasil persepsi langsung indra terhadap objek, dan penampakan dunia luar pada indra yang penampakan tersebut bukan merupakan substansi objek yang sesungguhnya melainkan hanya halusinasi, seperti apa yang dilihat orang tidur, orang sakit dan gambar malaikat pada Nabi.

b. Wujud khayali adalah gambar sebuah objek yang ada dalam potensi khayal (common sense). Maksudnya data yang sudah terinternalisasi ke dalam mental subjek dan disimpan dalam potensi memori (hafizah) seseorang. ${ }^{15}$

c. Wujud 'aqli adalah makna abstrak yang ditangkap oleh rasio dari sebuah objek, berdasarkan 'sense data' (wujud hissi dan wujud khayali), tetapi sudah terlepas dari pengaruh indra dan khayal itu sendiri, seperti pemahaman bahwa hakikat manusia adalah hewan berfikir. ${ }^{16}$

Begitu juga menurut al-Farabi, wujud semua benda alami, benda bumi, terbagi dalam dua jenis; wujud aktual dan wujud potensial. Suatu benda hanya akan tetap menjadi sebuah entitas potensial sepanjang masih berupa materi tanpa bentuk. Benda tersebut akan menjadi ada -secara aktual- jika bentuknya ada. Dalam pandangan al-Farabi, bentuk adalah prinsip ontologis yang lebih unggul dari materi karena bentuk-lah yang mengaktualisasikan materi. Materi ada semata-mata karena adanya bentuk, jika tidak ada bentuk dalam eksistensinya, maka materi juga tidak mungkin ada.

Menurut al-Farabi, semua benda ini pada asalnya hanya ada dalam

15 Kedua wujud ini, oleh sebagian filosof barat moden, seperti aliran realism kritis, dipandang sebagai 'sense data' yang menghubungkan pikiran subjek dengan objek.

16 Ibid., hlm. 89-90. dan Saeful, Filsafat Ilmu al-Ghazali, hlm. 125-127. Lihat: Hamish Ihya' 'Ulum al-Din, I/79.

164 JURNAL LISAN AL-HAL 
potensinya. Tidak ada satu pun benda yang muncul secara aktual sejak dari sebelumnya. Pada permulaannya, ia hanya ada secara potensial dalam 'materi pertama universal' (al-maddah al-ula al-mushtarakah), suatu eksistensi non fisik yang dianggap sebagai produk abadi materi langit. Dari materi pertama inilah muncul sumber benda-benda bumi, yakni air, udara, api dan tanah, yang dari campuran keempat materi awal tersebut kemudian muncul benda-benda lainnya. Benda-benda yang awalnya ada secara potensial memperoleh eksistensinya secara aktual.

Setelah benda-benda potensial itu memperoleh aktualitasnya di bumi atau di alam nyata, berdasarkan kualitas unsur-unsur campuran yang membentuknya, al-Farabi membagi lagi benda-benda bumi ini ke dalam beberapa tingkatan hirarki, yaitu: 1) Manusia (ajsam al-adamiyyin); 2) Binatang (ajsam al-hayawanat);3) Tumbuhan (ajsam al-nabatat); 4) Mineral (ajsam al-ma'adin); dan 5) Gabungan keempat unsur (al-mawad al-awwaliyat al-mushtarikah), berupa air, udara, api dan tanah. Manusia menempati posisi yang paling sempurna, karena selain memiliki jiwa tumbuhan dan jiwa tak-rasional, ia juga memiliki jiwa rasional atau daya berfikir. ${ }^{17}$

Dalam kaitannya dengan pemikiran ontologis, konsep wujud aktual dan potensial ini berkaitan dengan 'necessitas' dan 'kontingensi'. Tidak jauh beda dengan Al-Farabi (870-950 M), dalam konsep Al-Ghazali, wujud aktual adalah sesuatu yang telah ada secara konkret, nyata, yang disebut wajib al-wujud (necessitas). ${ }^{18}$ Sementara itu wujud potensial adalah sesuatu yang masih ada dalam konsep atau ide, dan siap untuk menjadi wujud konkret yang mengenal ruang dan waktu. Namun wujud potensial ini masih dalam posisi mumkin al-wujud (kontingensi), ${ }^{19}$ di mana kemungkinan adanya tidak lebih kuat dari tiadanya, sehingga ia akan tetap dalam kondisi seperti itu selama belum berubah menjadi realitas yang aktual. ${ }^{20}$

Menurut Al-Ghazali, imkan (kontingensi) tidak ekuivalen dengan realitas, dan wujub (necessitas) tidak dengan simplisitas. Persoalan imkan, wujub dan imtina' (kemustahilan) hanya hukum rasio yang tidak harus mempunyai objek secara aktual. Sebab, jika imkan butuh sandaran realitas

${ }^{17}$ A. Khudori, Ibid. hlm. 70-71.

18 Wajib al-wujud adalah wujud yang menurut akal mestilah ada, dan mustahil tidak ada. Lihat: Abdul Aziz Dahlan, Pemikiran Falsafi dalam Islam, (Jakarta: Djambatan, 2003), hlm.. 94.

${ }_{19}$ Mumkin al-wujud adalah wujud yang menurut akal tidak mesti ada, dan tidak mesti tidak ada (tidak mustahil ada). Lihat: Ibid.

${ }^{20}$ A. Khudori, Wacana Baru, hlm. 91. 
aktual berupa materi, maka kemustahilan juga membutuhkannya. Sesuatu yang tidak bisa diterima nalar. ${ }^{21}$

\section{Wujud Mutlak dan Wujud Nisbi}

Dalam perspektif ontologis Ibn 'Arabi, wujud terbagi dalam dua bagian; wujud mutlak dan wujud nisbi. Wujud mutlak adalah sesuatu yang eksis dengan dirinya sendiri dan untuk dirinya sendiri, dan itu adalah Tuhan. Wujud nisbi adalah sesuatu yang eksistensinya terjadi oleh dan untuk wujud lain (wujud bi al-ghair). Wujud nisbi ini terbagi dalam dua bagian; wujud bebas dan wujud bergantung, yang disebut kedua ini berupa atribut-atribut, kejadian-kejadian dan hubungan-hubungan yang bersifat spesial dan temporal. Sementara itu, wujud nisbi bebas berupa substansi-substansi, dan ia terbagi dalam dua bagian; material dan spiritual. ${ }^{22}$

Namun yang perlu dicatat, apa yang dianggap wujud nisbi tersebut tidak sepenuhnya entitas temporal melainkan juga entitas permanen (ala'yan al-thabitah) sebagaimana wujud mutlak. Dalam pandangan Ibn 'Arabi, semua yang ada dalam semesta ini -dalam semua keadaannyatelah ada dan persis seperti apa yang ada dalam ilmu Tuhan sejak 'azali, dan apa yang ada dalam ilmu Tuhan itu adalah al-a'yan al-thabitah. Setiap urusan dan apa yang ada dalam semesta tidak pernah keluar dari rencana yang telah ditetapkan oleh Tuhan sejak permulaan dalam ilmu-Nya. ${ }^{23}$

Dalam struktur ontologis Ibn 'Arabi, 'entitas-entitas permanen' menempati posisi tengah antara Tuhan dan semesta, antara Al-Haqq dalam keabsolutan-Nya dan alam nyata. Kedudukan ontologisnya sebagai posisi tengah antara Tuhan dan semesta membuat 'entitas-entitas permanen' bersifat pasif dan aktif sekaligus. Ia bersifat pasif dalam hubungannya dengan apa yang lebih tinggi dari padanya, yaitu Tuhan. Ia bersifat aktif dalam hubungannya dengan apa yang lebih rendah dari padanya, yaitu alam nyata. Kepasifan dan keaktifannya terjadi dalam penampakan diri (tajalli) Tuhan, yang berarti sama dengan proses penciptaan semesta dalam konsep emanasi. ${ }^{24}$

${ }^{21}$ Al-Ghazali, Tahafut al-Falasifah, (edit), Sulayman Dunya, (Cairo: Dar al-Ma'arif, VIII/2000), hlm. 118-123.

${ }^{22}$ A. Khudori, Wacana Baru, hlm. 145.

${ }^{23}$ Kautsar, Ibn al-'Arabi, hlm. 120.

${ }^{24}$ Ibid., hlm. 121-122.

166 JURNAL LISAN AL-HAL 


\section{Partikular dan Universal}

Sejalan dengan konsep di atas, dari sisi 'esensial', al-Ghazali membagi realitas dalam dua bagian; partikular (juz'iyyat) dan universal (kulliyyat). Partikular diklasifikasikan menurut 10 kategori Aristoteles, yaitu satu substansi (jauhar) dan sembilan aksiden ('arad\}), yakni: kuantitas (kammiyyah), kualitas (kayfiyyah), relasi (idhafah), di mana (ayna), kapan (mata), postur (wadha), posesi (lahu/milkiyyah), aksi (an yaf'ala) dan passi (an yanfa'ila). ${ }^{25}$

Kemudian mengenai realitas universal, al-Ghazali membagi dalam dua bagian; (1) universal esensial (dhati) yang mencakup genus (jins), spesies (naw) dan differense (fas\}l), (2) universal aksidental ('arad\}), baik yang khusus seperti 'tertawa' pada manusia, atau yang umum seperti sifat 'bergerak' pada materi. Universal esensial adalah makna abstrak tanpa melihat atribut-atribut luar yang menyertainya, sedangkan universal aksidental adalah konsep abstrak yang merupakan generalisasi dari adanya kesamaan-kesamaan dari partikular-partikular. Perbedaan diantara keduanya adalah bahwa yang pertama ada dalam konsep mental sekaligus dalam realitas aktual, yakni bahwa esensi dari universalisme tersebut memang benar-benar wujud alam realitas, sementara yang kedua hanya ada dalam konsep mental, tidak ada dalam realitas aktual, karena tidak mungkin sesuatu yang satu menjadi atribut bagi berbagai partikular lainnya dalam waktu yang bersamaan.

Dengan demikian, universal dalam arti kedua bukanlah substansi primer yang mempunyai wujud dalam realitas aktual, melainkan sematamata substansi kedua yang hanya berwujud dalam konsep mental. Selanjutnya al-Ghazali menegaskan: "Jauhar kulli (substansi universal) terbentuk di atas partikular-partikular, sebab tanpa partikular-partikular itu, universal tidak terwujud. Maka partikular dalam rutbah mendahului universal, tetapi partikular dalam menjadi konsep mentalnya membutuhkan universal, dan tidak membutuhkannya dalam realitas aktual."26 Dengan demikian, tidak dapat diterima adanya universal tanpa adanya sandaran yang berupa partikular-partikular. ${ }^{27}$ Seperti al-Farabi dan Ibn Sina, alGhazali mengakui bahwa indra hanya dapat menangkap partikularpartikular (juz'iyyat), sedangkan akal hanya dapat menangkap universaluniversal (kulliyyat).

${ }^{25}$ Saeful, Filsafat Ilmu al-Ghazali, hlm. 128.

26 Ibid., 134-135.

27 Al-Ghazali, Tahafut, 272. 


\section{Simpulan}

Wujud terbagi dua; (1) wujud aktual yang eksistensinya hanya ada dalam mental, konsep dan pikiran, tetapi konkret, nyata dalam wujud realitas, dan (2) wujud potensial yang hanya ada dalam konsep, mental atau pikiran dan masih dalam posisi imkan, dan pada gilirannya akan bisa mengarah pada kesimpulan bahwa aksiden lebih penting dari pada substansi, karena aksiden itulah yang menentukan eksistensi sesuatu. Ini tidak berbeda dengan konsep al-Farabi.

Disisi lain, dengan konsep wujud aktual-potensial tersebut berarti pula bahwa semua yang konkret telah ada gambarannya dalam pikiran, termasuk wujud semesta telah ada gambarannya dalam benak Tuhan sebagai wujud potensial. Al-Ghazali mengakui hal ini dan menamakan dengan nashiyah azaliyah (kehendak azali). Ini berarti tidak berbeda dengan konsep 'keqadiman alam' dari filsafat al-Farabi, bahwa semesta ini telah ada wujudnya dalam pikiran Tuhan secara azali bersama keazalianNya.

Pemikiran al-Ghazali tentang dua kutub realitas, partikular dan universal, yang keduanya sama-sama merupakan substansi yang mempunyai bangunan tersendiri tetapi saling berkaitan, kiranya adalah gagasan yang genius. Dengan demikian, doktrin kaum teolog bahwa semesta diciptakan dari sesuatu yang tiada itu bisa dijelaskan, sehingga perbedaan antara doktrin teologi dan filsafat bisa terselesaikan.

\section{DAFTAR PUSTAKA}

Anwar, Saeful, DR. H. M.A. Filsafat Ilmu Al-Ghazali: Dimensi Ontologi dan Aksiologi. Bandung: Pustaka Setia, I/2007.

Dahlan, Abdul Aziz. Prof. Dr. Pemikiran Falsafi dalam Islam. Jakarta: Djambatan, 2003.

Departemen Agama Republik Indonesia. Al-Qur'an dan Terjemahnya. Surabaya: CV. Ramsa Putra, X/2005.

Ghazali (al). Ih\}ya' 'Ulum al-Din. Beirut: Dar al-Fikr, t.th. Taha>fut al-Falasifah. (edit), Sulayman Dunya. Cairo: Dar al-Ma'arif, VIII/2000.

Gie,The Liang. Pengantar Filsasat Ilmu. Yogyakarta: Liberty, 2004.

Jurjni> (al). al-Ta'rifat. Singapur-Jeddah: al-H\{aramain, t.th.

Noer, Kautsar Azhari, DR. Ibn al-'Arabi: Wahdat al-Wujud dalam Perdebatan. Jakarta: Paramadina, I/1995.

Rozak, Zaedi Basitur. "Eksistensialisme Persfektif Filsafat Mulla Sadra". Dalam,http://www.blogspot.com.eksistensialisme-persfektif-

168 JURNAL LISAN AL-HAL 
"Volume 12, No. 1, Juni 2018"

filsafat.html. (Juli 2017).

Soleh, A. Khudori. M.Ag. Wacana Baru Filsafat Islam. Yogyakarta: Pustaka Pelajar, I/2004. 
"Hakikat Wujud"

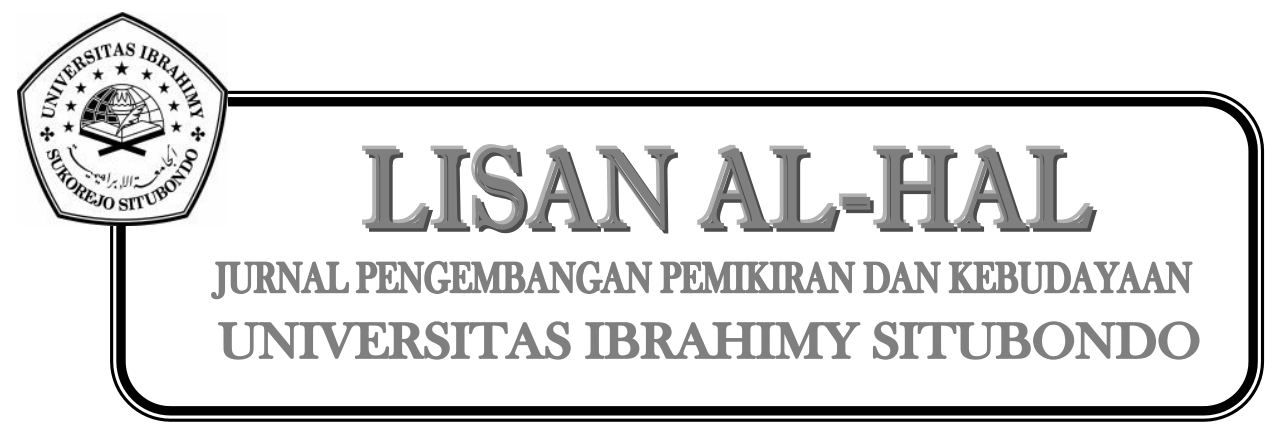

170 JURNAL LISAN AL-HAL 